\title{
ARBUSCULAR MYCORRHIZA AND KINETIC PARAMETERS OF PHOSPHORUS ABSORPTION BY BEAN PLANTS
}

\author{
Adriana Parada Dias da Silveira ${ }^{1 *}$; Elke Jurandy Bran Nogueira Cardoso ${ }^{2}$ \\ ${ }^{1}$ IAC - Centro de Pesquisa e Desenvolvimento em Solos e Recursos Ambientais, C.P. 28 - 13001 -970 - Campinas, \\ $S P$ - Brasil. \\ ${ }^{2}$ USP/ESALQ - Depto. de Solos e Nutrição de Plantas, C.P. 09 - 13418-900 - Piracicaba, SP - Brasil. \\ *Corresponding author 〈apdsil@iac.sp.gov.br>
}

\begin{abstract}
The mechanisms that determine greater $\mathrm{P}$ absorption by mycorrhizal plants are still not completely clear, and are attributed, in part, to an increase in the number of absorption sites promoted by the hyphae, and/ or to a greater affinity of the colonized hypha or root carriers to P. The effect of mycorrhizae formed by Glomus etunicatum on the kinetic parameters of $\mathrm{P}$ absorption by the roots and on $\mathrm{P}$ influx in bean plants of the IAC-Carioca cultivar was evaluated, in two distinct plant development periods: at the onset of flowering and at the pod-filling stage ( 35 and 50 days after sowing, respectively). A mixture of sand and silica (9:1) was utilized as substrate and irrigated with nutrient solution. The kinetics assay was performed by the method of ${ }^{32} \mathrm{P}$ depletion from the solution (depletion curve), using intact plants. Mycorrhization promoted greater growth and $\mathrm{P}$ absorption by bean plants, which was more conspicuously observed at the pod-filling stage. Mycorrhizal plants showed higher values of maximum ion uptake rate $\left(\mathrm{V}_{\max }\right)$ and net $\mathrm{P}$ influx at the flowering stage. Lower minimum ion concentration $\left(\mathrm{C}_{\min }\right)$ and Michaelis-Menten constant $\left(\mathrm{K}_{\mathrm{m}}\right)$ values were verified in mycorrhizal plants at the pod-filling stage. Mycorrhizal plants also presented higher net $\mathrm{P}$ influx per plant, in both stages. $\mathrm{C}_{\min }$ was the kinetic parameter more intimately related to $\mathrm{P}$ absorption, and a significant correlation was obtained between this parameter and shoot $\mathrm{P}$ content and accumulation in bean plants.

Key words: Phaseolus vulgaris, arbuscular mycorrhizal fungus, absorption kinetics, phosphorus influx, bean
\end{abstract}

\section{MICORRIZA ARBUSCULAR E OS PARÂMETROS CINÉTICOS DE ABSORÇÃO DE FÓSFORO PELO FEIJOEIRO}

\begin{abstract}
RESUMO: Os mecanismos envolvidos na maior absorção de P pela planta micorrizada ainda não estão totalmente esclarecidos, atribuindo-se, em parte, ao aumento no número de sítios de absorção promovido pela hifa e/ou maior afinidade dos carregadores da hifa ou da raiz colonizada ao P. Avaliou-se o efeito da micorriza formada por Glomus etunicatum nos parâmetros cinéticos da absorção radicular de $\mathrm{P}$ e no influxo de P em feijoeiro, cultivar IAC-Carioca, em duas épocas do ciclo da planta, início do florescimento e enchimento das vagens (35 e 50 dias após semeadura, respectivamente). Empregou-se como substrato areia e sílica (9:1) irrigado com solução nutritiva. O ensaio de cinética foi realizado pelo método do esgotamento do ${ }^{32} \mathrm{P}$ da solução (curva de depleção), empregando-se a planta inteira. A micorrização promoveu maior crescimento e absorção de $\mathrm{P}$ pelas plantas, principalmente na fase de enchimento das vagens. As plantas micorrizadas que se encontravam no estádio de florescimento tiveram maior velocidade máxima de absorção $\left(\mathrm{V}_{\max }\right)$ e influxo líquido de $\mathrm{P}$. Menores valores de concentração mínima de $\mathrm{P}$ na solução $\left(\mathrm{C}_{\min }\right)$ e da constante de MichaelisMenten $\left(\mathrm{K}_{\mathrm{m}}\right)$ foram constatados nas plantas micorrizadas, na fase de enchimento das vagens. As plantas micorrizadas também apresentaram maior influxo líquido de $\mathrm{P}$ por planta, em ambas as fases. A $\mathrm{C}_{\min }$ foi o parâmetro que mais se relacionou com a absorção de $\mathrm{P}$, ocorrendo correlação significativa entre este e o teor e acúmulo de $\mathrm{P}$ na parte aérea do feijoeiro.

Palavras-chave: Phaseolus vulgaris, fungo micorrízico arbuscular, cinética de absorção, influxo de fósforo, feijão
\end{abstract}

\section{INTRODUCTION}

Absorption of soil nutrients by roots depends, among several factors, on ion movement in the soil and on the root absorption ability. This, in turn, is a function of the root system morphology and physiology, and directly influenced by microorganisms in the rhizosphere, which could either maintain only superficial contact or dwell inside the root tissues. Most legumes, such as bean plants, possess two types of symbiotic microorganisms in their roots, namely atmospheric $\mathrm{N}_{2}$-fixing bacteria and mycorrhizal fungi, thus establishing a triple association capable of supplying plants especially with regard to their $\mathrm{N}$ and P requirements (Silveira \& Cardoso, 1987).

From a nutritional point of view, the great importance of arbuscular mycorrhizae lies precisely on the 
fact that they increase the plant ability to absorb nutrients, especially those with little mobility in the soil, such as $\mathrm{Cu}, \mathrm{Zn}$, and $\mathrm{P}$ in particular. This promoting effect of mycorrhizae is more pronounced under conditions of low $P$ availability in the soil, as it is the case of the great majority of tropical soils.

In spite of the fact that mycorrhizal plants show greater $\mathrm{P}$ accumulation in their tissues than non-mycorrhizal ones, the mechanisms involved in $\mathrm{P}$ absorption by mycorrhizae are still not completely understood. The symbiosis effect is attributed to the microsymbiont external hyphae, which function as an extension of the root system, providing a more extensive and better-distributed nutrient absorption surface, and imparting greater soil exploration capacity, beyond the $\mathrm{P}$ depletion zone, as well as greater ion absorption ability (Silveira, 1992).

Some papers dealing with root $\mathrm{P}$ absorption kinetics have been conducted to clarify whether this greater absorption occurs because of an increase in the number of absorption sites promoted by hyphae and/or because of the greater affinity of the hyphae or colonized root carriers to $\mathrm{P}$. Results, however, are contradictory. Karunaratne et al. (1986) and Faquin et al. (1990) observed an increase in P absorption as a consequence of greater number of absorption sites promoted by the hyphae (greater $\mathrm{V}_{\max }$ ), while Cress et al. (1979) verified that, under low $\mathrm{P}$ concentrations in the solution, the absorption by the mycorrhizal plant was associated with a lower $\mathrm{K}_{\mathrm{m}}$ value, i.e., with greater affinity of the colonized root carriers and/or the hyphae to $\mathrm{P}$. The $\mathrm{P}$ absorption kinetic parameters, as well as $\mathrm{P}$ influx in mycorrhizal plants, are influenced by factors such as cultivar-mycorrhizal fungus combination and level of $\mathrm{P}$ that is added to the substrate (Silveira, 1990). Mycorrhization in soybean may decrease $\mathrm{K}_{\mathrm{m}}$ and $\mathrm{C}_{\min }$, which also experience alterations in roots presenting double symbiosis: mycorrhizal fungus and rhizobium (Silveira \& Cardoso, 1991). Again in soybean, Silveira $\&$ Cardoso (1994) verified that even when aluminum was added to the substrate, mycorrhizal plants had lower $\mathrm{K}_{\mathrm{m}}$ and $\mathrm{C}_{\min }$ values, especially in the Al-intolerant cultivar, and greater $\mathrm{P}$ influx. For citrus plants, depending on the availability of $\mathrm{P}$ in the substrate, the $\mathrm{P}$ uptake kinetic parameters can vary and are related to the beneficial or parasitic effect of the arbuscular mycorrhizal fungus-AMF (Cunha, 1999).

The ionic absorption kinetic parameters are influenced by several factors in addition to the mycorrhizae, and especially by plant age (Edwards \& Barber, 1976; Drew et al., 1984). Therefore, the objective of this work was to evaluate the effect of mycorrhizae on the kinetic parameters of $\mathrm{P}$ absorption by the roots and on $\mathrm{P}$ influx in bean plants, during two distinct plant development stages: at the onset of flowering, and at pod filling.

\section{MATERIAL AND METHODS}

The experiment was carried out under greenhouse conditions, in a completely randomized design, with eight replicates, arranged in a $3 \times 2$ factorial scheme, as follows: three treatments - inoculation of AMF Glomus etunicatum and two controls without inoculation, one in which plants received $3.0 \mathrm{mg} \mathrm{L}^{-1}$ of $\mathrm{P}\left(\mathrm{C}-\mathrm{P}_{1}\right)$, and the other where plants received $30.0 \mathrm{mg} \mathrm{L}^{-1} \mathrm{P}\left(\mathrm{C}-\mathrm{P}_{2}\right)$ in the nutrient solution, evaluated at two stages of the plant development cycle- at the onset of flowering (35 days after sowing, DAS) and at pod filling (50 DAS).

A medium-to-fine-grade, washed sand mixed with ground silica $(9: 1)$ was utilized as substrate. The silica was washed in running water and autoclaved at $121^{\circ} \mathrm{C}$ for 1.5 hour. The sand, previously washed in running water, was sterilized in flowing steam for two hours, during three consecutive days and, because of its lack of purity, already contained $5 \mathrm{mg} \mathrm{dm}^{-3} \mathrm{P}$ (P resin). The $2.5-\mathrm{kg}$ pots were lined internally with plastic bags containing holes in the bottom to facilitate removal of the entire plant and transfer to the nutrient solution, without damaging the root system. A 2-cm layer of medium-sized crushed stone, washed in running water and sterilized at $121^{\circ} \mathrm{C}$ for 1.5 hour, was placed in the bottom of the pots to facilitate drainage of the solution.

The AMF inoculum, previously multiplied in stock pots planted with maize, was spread throughout the entire pot surface at a five-cm depth, and consisted of 50 $\mathrm{cm}^{3}$ soil containing pieces of infected roots, hyphae, and approximately 2,000 spores. The controls received the same volume of soil as in the control stock-pot, containing pieces of maize root but without mycorrhizal fungus propagules.

Bean seeds of cultivar IAC-Carioca were disinfected superficially with $1.5 \%$ sodium hypochlorite for five minutes, and washed with distilled water. Next, they were submersed for 15 minutes in a rhizobium cell suspension, obtained in a mannitol-yeast extract liquid medium (Vincent, 1970) under agitation. The Rhizobium phaseoli strains were: C- 05 II, CIAT 1899 and C- 88. Sowing was performed by placing eight seeds per pot, onto which were added $10 \mathrm{~mL}$ of rhizobium suspension. Thinning was made ten days after sowing leaving one plant per pot, and again $10 \mathrm{~mL}$ of rhizobium suspension were added to the plant root collar.

From planting through thinning, the pots only received distilled water. From then on, $100 \mathrm{~mL}$ of no. 2 Hoagland and Arnon solution, modified by Faquin et al. (1990), were added weekly, in a free-drainage system, and irrigation was performed with distilled water as needed. For treatments that received AMF inoculation and for one of the controls $\left(\mathrm{C}-\mathrm{P}_{1}\right)$, the $\mathrm{P}$ concentration in the solution that was applied weekly was $3.0 \mathrm{mg} \mathrm{L}^{-1}$, while for the other control $\left(\mathrm{C}-\mathrm{P}_{2}\right)$, the concentration was $30.0 \mathrm{mg} \mathrm{L}^{-1}$. 
The plants received $\mathrm{N}$ in stages, in the form of $\mathrm{KNO}_{3}$, $30 \mathrm{mg} \mathrm{L}^{-1}$ at thinning and $30 \mathrm{mg} \mathrm{L}^{-1}$ twenty days later.

At harvest, the plants were carefully removed from the pots by pulling the plastic bag which, once cut, allowed the substrate to be eliminated. The root system was dipped into successive water tanks to minimize damage to the roots and avoid, as much as possible, detachment of nodules and external hyphae of the mycorrhizal fungus.

In four replicates, the plants were cut at root collar height and the shoot was dried to determine shoot dry weight. The plant shoot was crushed and digested for $\mathrm{P}$ content determination (Sarruge \& Haag, 1974). The root system was washed and placed in 50\% alcohol. The percentage of root length colonized by the mycorrhizal fungus was estimated by the Ambler \& Young (1977) method, after trypan blue staining in lacto-glycerol (Phillips \& Hayman, 1970).

The characterization of $\mathrm{P}$ absorption kinetics by the roots and determination of kinetic parameters were performed by the method of $\mathrm{P}$ depletion from the solution as a function of absorption time (depletion curve), according to the method proposed by Claassen \& Barber (1974), utilizing intact plants and a low P concentration in the solution. The plants removed from the solid substrate were transferred to a growth nutrient solution corresponding to the treatments, and the $\mathrm{pH}$ was maintained at 5.5 (adjusted with $\mathrm{NaOH}$ or $\mathrm{HCl}$ ), in three-liter plastic pots, under constant aeration, still maintained for three days in the greenhouse. Forty hours prior to the beginning of the kinetics assay, plants were transferred to the absorption, P-free nutrient solution, with the following composition: $\mathrm{N}=14.0 ; \mathrm{K}=11.7 ; \mathrm{Ca}=12.0 ; \mathrm{Mg}=2.43$; $\mathrm{S}=3.2 ; \mathrm{B}=0.25 ; \mathrm{Cu}=0.01 ; \mathrm{Mn}=0.25 ; \mathrm{Mo}=0.005$; $\mathrm{Zn}=0.025 \mathrm{mg} \mathrm{L}^{-1}$ (Faquin et al., 1990). After that, plants were taken to the laboratory, under a lighting system consisting of a set of 250 Watt HPLO (Phillips) light bulbs, which provided a light intensity of $35 \mathrm{Watt}^{-2}$ at the upper level leaves; the mean temperature in the room was $24^{\circ} \mathrm{C}$. The plants were transferred to a new solution with identical composition, but with the addition of $10 \mathrm{mmol}$ $\mathrm{L}^{-1} \mathrm{P}\left(0.31 \mathrm{mg} \mathrm{L}^{-1}\right)$ in 2.5 -L capacity pots, according to determinations established in a previous assay, where they remained for $1.5 \mathrm{~h}$. After that period, the plants were transferred to the absorption solution with $\mathrm{P}$ concentration and solution volume previously determined, but with $40 \mu \mathrm{Ci}{ }^{32} \mathrm{P}$ per pot, in the form of carrier-free $\mathrm{NaH}_{2}^{32} \mathrm{PO}_{4}$. The absorption period had a duration of $12 \mathrm{~h}$, and samplings were taken at every half hour up to the fifth hour, and at one-hour intervals after that, totaling 18 samplings per pot, with two replicates. The solution samples, $1 \mathrm{~mL}$ aliquots, were placed in scintillation vials with $14 \mathrm{~mL}$ demineralized water, and the ${ }^{32} \mathrm{P}$ activity was determined by the Cerenkov effect (Nascimento Filho \& Lobão,
1977) in a liquid scintillation beta spectrometer. Plants were kept under constant aeration during the entire assay and the $\mathrm{pH}$ in the solution, initially adjusted to 5.0, was not corrected during the absorption period.

The pot + plant weight was determined at the beginning and at the end of the assay for later estimate of transpiration and correction of the solution volume in the pot, at each sampling time. At the end of the assay, the root system was separated from the shoot, washed in running water, and dried with paper towels for fresh matter weight determination.

Once the P depletion curve in the solution as a function of absorption time was obtained, the kinetic parameters of root $\mathrm{P}$ absorption $\left(\mathrm{V}_{\max }\right.$ and $\left.\mathrm{K}_{\mathrm{m}}\right)$ were estimated by the graphical-mathematical approximation proposed by Ruiz (1985). $\mathrm{C}_{\min }$ was determined by the $\mathrm{P}$ concentration values mean in the solution, from the final samplings. Once the kinetic parameters had been estimated, it was possible to define the Michaelis-Menten equation and to calculate the net influx: $\mathrm{I}=\left[\mathrm{V}_{\max } \cdot\left(\mathrm{C}-\mathrm{C}_{\min }\right)\right]\left[\mathrm{K}_{\mathrm{m}}\right.$ $\left.+\left(\mathrm{C}-\mathrm{C}_{\min }\right)\right]^{-1}$, expressed per unit of root fresh matter weight and per plant. Data were submitted to analysis of variance and the Tukey test at 5\% was utilized to compare means.

\section{RESULTS}

The velocity of $\mathrm{P}$ exhaustion from the nutrient solution (Figure 1) shows that up to the fourth hour of absorption the mycorrhizal plants had a similar behavior, but from that time forward older plants (50 DAS) depleted $P$ faster than younger ones (35 DAS). The control plants were slower in absorbing $\mathrm{P}$, especially $\mathrm{C}_{-} \mathrm{P}_{1}$ at $35 \mathrm{DAS}$ and $\mathrm{C}-\mathrm{P}_{2}$ at 50 DAS.

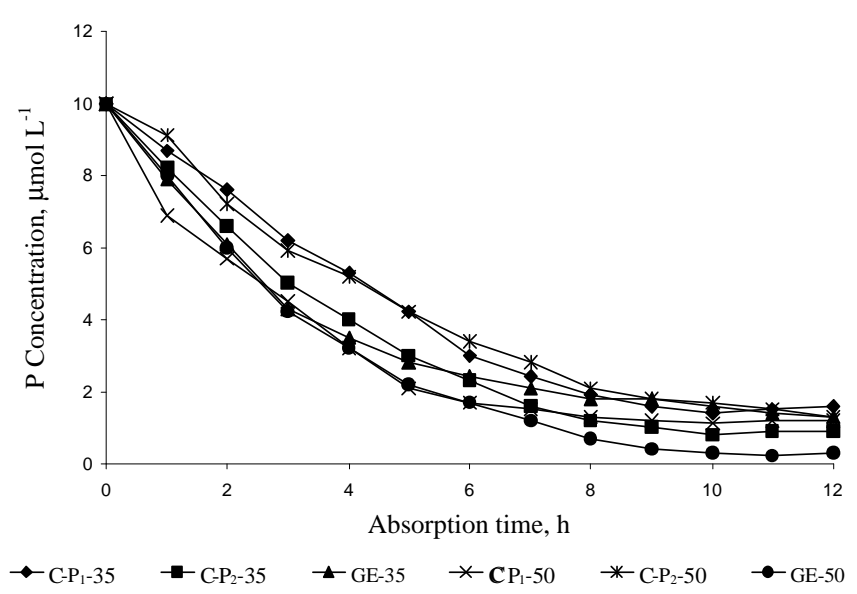

Figure 1 - Depletion curve of $\mathrm{P}$ from nutrient solution by nonmycorrhizal (C-P ${ }_{1}^{-}$Control with $3.0 \mathrm{mg} \mathrm{L}^{-1}$; C- $\mathrm{P}_{2}$ Control with $30.0 \mathrm{mg} \mathrm{L}^{-1} \mathrm{P}$ ) and mycorrhizal (GEGlomus etunicatum) bean plants, at the onset of flowering and at the pod-filling stages (35 and 50 days after sowing, respectively). 
The kinetic parameters of root $\mathrm{P}$ absorption were influenced by the mycorrhization of bean plants and varied with plant age (Table 1). In general, $\mathrm{V}_{\max }$ was higher at 35 DAS, differing $100 \%$ from the velocity observed at $50 \mathrm{DAS}$, when the roots were colonized by $G$. etunicatum, surpassing the control with the lowest $\mathrm{P}$ level $\left(\mathrm{C}-\mathrm{P}_{1}\right)$ by $80 \%$, and also the control with the highest $\mathrm{P}$ level $\left(\mathrm{C}-\mathrm{P}_{2}\right)$, by $64 \%$.

Carrier affinity to $\mathrm{P}$ was higher when the roots were colonized by G. etunicatum (Table 1), i.e., the $\mathrm{K}_{\mathrm{m}}$ values for mycorrhizal plants were $34 \%$ and $24 \%$ lower, at $35 \mathrm{DAS}$, and $23 \%$ and $40 \%$ lower, at $50 \mathrm{DAS}$, than the C-P and $\mathrm{C}-\mathrm{P}_{2}$ values, respectively. $\mathrm{K}_{\mathrm{m}}$ did not change with plant age. At $35 \mathrm{DAS}$, the control plants with the higher level of $\mathrm{P}\left(\mathrm{C}-\mathrm{P}_{2}\right)$ presented a lower $\mathrm{C}_{\min }$ than $\mathrm{C}$ $\mathrm{P}_{1}$, not different, however, from the mycorrhizal plants. At 50 DAS, however, there was a $78 \% \mathrm{C}_{\min }$ decrease in the mycorrhizal plants, differing from the non-mycorrhizal ones.

Bean plant mycorrhization promoted greater net $P$ influx per unit of root fresh matter weight (Figure 2A). At 35 DAS, the net influx in the mycorrhizal plants was, on the average, 110 and $68 \%$ higher than in $\mathrm{C}_{-} \mathrm{P}_{1}$ and $\mathrm{C}$ $\mathrm{P}_{2}$, respectively. At 50 DAS, the mycorrhizal plant influx was $30 \%$ higher than in $\mathrm{C}-\mathrm{P}_{2}$. The net $\mathrm{P}$ influx by mycorrhizal plants was, on the average, $110 \%$ higher at 35 DAS than at 50 DAS.

Table 1 - Kinetic parameters $\left(\mathrm{V}_{\max }, \mathrm{K}_{\mathrm{m}}, \mathrm{C}_{\min }\right)$ of $\mathrm{P}$ uptake and root fresh matter weight (RFW) of non-mycorrhizal (C-P $\mathrm{P}_{1}$ : Control with $3.0 \mathrm{mg} \mathrm{L}^{-1}$; C-P : Control with $30.0 \mathrm{mg} \mathrm{L}^{-1} \mathrm{P}$ ) and mycorrhizal (GE- Glomus etunicatum) bean plants, at the onset of flowering and at the pod-filling stages, 35 and 50 days after sowing (DAS), respectively.

\begin{tabular}{|c|c|c|c|}
\hline DA S/Treatments & $\mathrm{C}-\mathrm{P}_{1}$ & $\mathrm{C}-\mathrm{P}_{2}$ & $\mathrm{GE}$ \\
\hline & \multicolumn{3}{|c|}{$\mathrm{V}_{\text {max }}\left(\mu \mathrm{mol} \mathrm{P} \mathrm{g}^{-1} \mathrm{~h}^{-1}\right)$} \\
\hline 35 DAS & $0.30 \mathrm{bA}$ & $0.33 \mathrm{bA}$ & $0.54 \mathrm{aA}$ \\
\hline \multirow[t]{2}{*}{50 DAS } & $0.21 \mathrm{aA}$ & $0.21 \mathrm{aA}$ & $0.27 \mathrm{aB}$ \\
\hline & \multicolumn{3}{|c|}{$\mathrm{K}_{\mathrm{m}}\left(\mu \mathrm{mol} \mathrm{P} \mathrm{L}^{-1}\right)$} \\
\hline $35 \mathrm{DAS}$ & $2.66 \mathrm{aA}$ & $2.29 \mathrm{aA}$ & $1.75 \mathrm{bA}$ \\
\hline \multirow[t]{2}{*}{$50 \mathrm{DAS}$} & $2.24 \mathrm{abA}$ & $2.84 \mathrm{aA}$ & $1.72 \mathrm{bA}$ \\
\hline & \multicolumn{3}{|c|}{$C_{\min }\left(\mu \mathrm{mol} \mathrm{PL}^{-1}\right)$} \\
\hline $35 \mathrm{DAS}$ & $1.56 \mathrm{aA}$ & $0.86 \mathrm{bA}$ & $1.33 \mathrm{abA}$ \\
\hline \multirow[t]{2}{*}{50 DAS } & $1.22 \mathrm{aA}$ & $1.26 \mathrm{aA}$ & $0.28 \mathrm{bB}$ \\
\hline & \multicolumn{3}{|c|}{ RFW (g) } \\
\hline $35 \mathrm{DAS}$ & $8.9 \mathrm{aB}$ & $11.7 \mathrm{aB}$ & $8.1 \mathrm{aB}$ \\
\hline 50 DAS & $14.0 \mathrm{aA}$ & $15.7 \mathrm{aA}$ & $16.5 \mathrm{aA}$ \\
\hline
\end{tabular}

Means followed by the same letter do not differ by the Tukey test at $5 \%$. Capital letter - comparison between plant stages at the same fungal treatment and small letter - comparison among fungal treatments at the same plant stage.
With regard to the net $\mathrm{P}$ influx per plant (Figure 2B), mycorrhizal plants, in both stages, were different from the controls, having similar behavior. The net influx in mycorrhizal plants, at $35 \mathrm{DAS}$, on the average surpassed $\mathrm{C}-\mathrm{P}_{1}$ by $85 \%$ and $\mathrm{C}-\mathrm{P}_{2}$ by $17 \%$, while at $50 \mathrm{DAS}$, this increment was $37 \%$ in relation to $\mathrm{C}_{-} \mathrm{P}_{1}$ and $57 \%$ in relation to $\mathrm{C}-\mathrm{P}_{2}$.

The mycorrhization effect on plant growth only occurred at 50 DAS (Table 2), and colonization of the plant by the fungus increased shoot dry matter by $87 \%$, in relation to $\mathrm{C}-\mathrm{P}_{1}$, but it was not different from $\mathrm{C}-\mathrm{P}_{2}$. When the two stages were compared, greater increment in growth $(240 \%)$ occurred in mycorrhizal plants than observed in the controls. The percentage of colonized root length was greater at 50 DAS (Table 2).
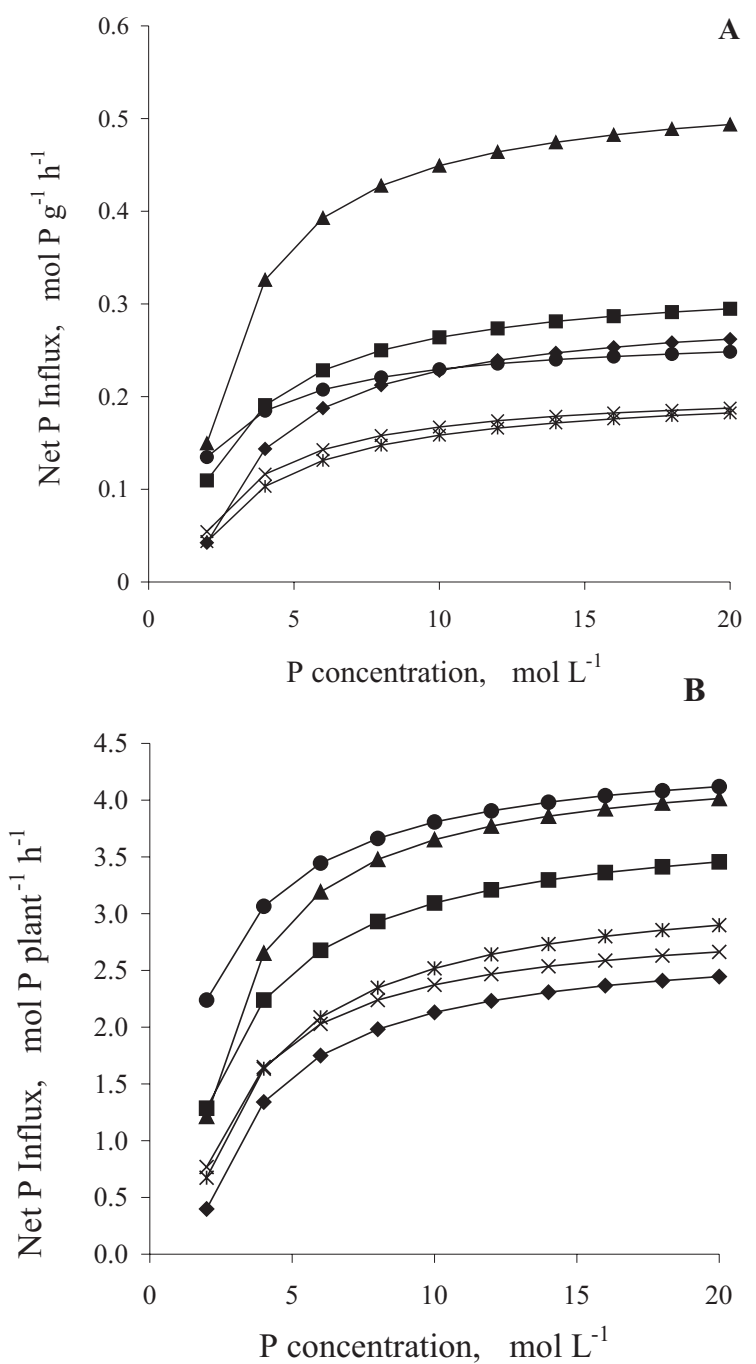

Figure 2 - Net Influx of P per unit root fresh matter weight (A) e per plant (B) as function of $\mathrm{P}$ concentration in the nutrient solution by non-mycorrhizal $\left(\mathrm{C}^{-} \mathrm{P}_{1}-\mathrm{Control}\right.$ with $3.0 \mathrm{mg} \mathrm{L}^{-1}$; C- $\mathrm{P}_{2}$ - Control with $30.0 \mathrm{mg} \mathrm{L}^{-1} \mathrm{P}$ ) and mycorrhizal (GE-Glomus etunicatum) bean plants, at the onset of flowering and at the pod-filling stages, 35 and 50 days after sowing (DAS), respectively. Curves follow the Michaelis-Menten equation. 
Table 2 - Shoot dry matter weight (SDW), shoot P content and accumulation and mycorrhizal colonization of non-mycorrhizal $\left(\mathrm{C}-\mathrm{P}_{1}\right.$ - control with $3.0 \mathrm{mg} \mathrm{L}^{-1}$ and $\mathrm{C}-\mathrm{P}_{2}-$ control with $30.0 \mathrm{mg} \mathrm{L}^{-1} \mathrm{P}$ ) and mycorrhizal (GE- Glomus etunicatum) bean plants, at the onset of flowering and at the pod-filling stages, 35 and 50 days after sowing (DAS), respectively.

\begin{tabular}{|c|c|c|c|}
\hline DAS/ Treatments & $\mathrm{C}-\mathrm{P}_{1}$ & $\mathrm{C}-\mathrm{P}_{2}$ & GE \\
\hline & \multicolumn{3}{|c|}{ SDW (g) } \\
\hline 35 DAS & $0.70 \mathrm{aB}$ & $1.10 \mathrm{aB}$ & $0.73 \mathrm{aB}$ \\
\hline \multirow[t]{2}{*}{50 DAS } & $1.33 \mathrm{bA}$ & $2.93 \mathrm{aA}$ & $2.48 \mathrm{aA}$ \\
\hline & \multicolumn{3}{|c|}{$P$ content $\left(\mathrm{g} \mathrm{kg}^{-1}\right)$} \\
\hline $35 \mathrm{DAS}$ & $1.50 \mathrm{bA}$ & $2.50 \mathrm{aA}$ & $1.60 \mathrm{bB}$ \\
\hline \multirow[t]{2}{*}{$50 \mathrm{DAS}$} & $1.60 \mathrm{bA}$ & $2.10 \mathrm{aA}$ & $2.40 \mathrm{aA}$ \\
\hline & \multicolumn{3}{|c|}{$\mathrm{P}$ accumulation (mg plant $\left.{ }^{-1}\right)$} \\
\hline 35 DAS & $1.08 \mathrm{bA}$ & $2.74 \mathrm{aB}$ & $1.35 \mathrm{bB}$ \\
\hline \multirow[t]{2}{*}{50 DAS } & $2.12 \mathrm{bA}$ & $6.27 \mathrm{aA}$ & $5.86 \mathrm{aA}$ \\
\hline & \multicolumn{3}{|c|}{ mycorrhizal colonization $(\%)$} \\
\hline 35 DAS & - & - & $24.21 \mathrm{~B}$ \\
\hline $50 \mathrm{DAS}$ & - & - & $69.85 \mathrm{~A}$ \\
\hline
\end{tabular}

Shoot $\mathrm{P}$ content of mycorrhizal plants did not differ from C-P plants, but was surpassed by plants wellsupplied in $\mathrm{P}\left(\mathrm{C}-\mathrm{P}_{2}\right)$, at 35 DAS. At 50 DAS, the mycorrhizal plants did not differ from $\mathrm{C}-\mathrm{P}_{2}$ with respect to $\mathrm{P}$ content, but were higher in $\mathrm{P}$ than $\mathrm{C}-\mathrm{P}_{1}$ (Table 2). In relation to shoot $\mathrm{P}$ accumulation, at 35 DAS C-P plants surpassed both $\mathrm{C}-\mathrm{P}_{1}$ and mycorrhizal plants, which did not differ between themselves. At 50 DAS, however, plants well supplied in $\mathrm{P}\left(\mathrm{C}-\mathrm{P}_{2}\right)$ and mycorrhizal plants were not different between themselves, but surpassed $\mathrm{C}$ $\mathrm{P}_{1}$ by $176 \%$.

\section{DISCUSSION}

There are few reports in the literature with the objective of determining the kinetic parameters of $\mathrm{P}$ absorption by mycorrhizal plants, in order to elucidate the mechanisms involved in the process of $\mathrm{P}$ absorption by the root under symbiosis. The physiological modifications that come from mycorrhiza establishment might interfere with absorption-related aspects, as well as with P translocation and utilization by the plant (Smith et al., 1994).

$\mathrm{V}_{\max }$ was smaller in older plants (50 DAS), in agreement with observations by Warncke \& Barber (1974) and Jungk \& Barber (1975) for maize, and Edwards \& Barber (1976) for soybean, but diverging from Drew et al. (1984) for barley, who did not obtain $\mathrm{V}_{\max }$ variation with plant age. $\mathrm{K}_{\mathrm{m}}$, however, practically did not change with plant age, a fact that was also observed for maize (Jungk \& Barber, 1975), but not for older soybean plants, for which $\mathrm{K}_{\mathrm{m}}$ increased (Edwards \& Barber, 1976). $\mathrm{C}_{\text {min }}$, however, not only varied with plant age, but also with treatment. While an increase in $\mathrm{C}_{\min }$ occurred with age in control-plants well supplied with $\mathrm{P}\left(\mathrm{C}-\mathrm{P}_{2}\right)$, as obtained by Edwards \& Barber (1976), a five-fold $\mathrm{C}_{\text {min }}$ reduction occurred for older mycorrhizal plants, which agrees with observations by Jungk \& Barber (1975); those authors, however, did not utilize mycorrhizal plants. Since the percentage of colonized root length tripled from 35 to $50 \mathrm{DAS}$, a hypothesis could be raised that this decrease in $\mathrm{C}_{\text {min }}$ occurred as a consequence of the increase of root colonization. Increases of plant growth caused by higher $\mathrm{P}$ absorption promoted by the presence of mycorrhiza is influenced by the integrity, extension and distribution of the external mycelium (Vilariño et al., 1993), which is correlated with the degree of colonization (Kucey \& Paul, 1982). Thus, the positive response of Glomus could not necessarily be due to greater root colonization, but perhaps to the external mycelium distribution in the soil.

In general, mycorrhizal plants presented higher $\mathrm{V}_{\max }$ and smaller $\mathrm{K}_{\mathrm{m}}$ and $\mathrm{C}_{\min }$ values. The increase in $\mathrm{V}_{\max }$ agrees with the observations by Karunaratne et al. (1986) and Faquin et al. (1990) for soybean, and constitutes an indication that there was an increase in the number of absorption sites per root unit, promoted by the fungus external hyphae, or by the number of carrier turns in the plasmatic membrane (Drew et al., 1984). A smaller $\mathrm{K}_{\mathrm{m}}$ values of mycorrhizal plants was observed by Cress et al. (1979) in roots detached from tomato plants. The smaller $\mathrm{C}_{\min }$ values observed for mycorrhizal plants at 50 DAS mean that the plants were capable of extracting and retaining $\mathrm{P}$ in the roots, even at low concentrations in the solution, in agreement with the results of Faquin et al. (1990). Silveira (1990), working with bean plants, and Silveira \& Cardoso (1991; 1994), working with soybean, observed that $\mathrm{K}_{\mathrm{m}}$ and $\mathrm{C}_{\min }$ are the kinetic parameters most influenced by mycorrhization, and can be dramatically reduced in mycorrhizal plants. In mycorrhizal roots, the fungal hypha is the main P absorption site (Ayling et al., 2001). This mechanism developed by mycorrhizae is important, especially in tropical regions, where $\mathrm{P}$ availability in the soil solution is low. In addition, this trait could be related to the adaptive factor of fungal species. It is interesting to point out that $\mathrm{K}_{\mathrm{m}}$ was negatively and significantly correlated $(P<0.05)$ with $\mathrm{V}_{\max }(\mathrm{r}=-0.51)$, suggesting that both mechanisms could have influenced $\mathrm{P}$ root absorption, which is characterized by an increase in the number of absorption sites and by their affinity to $\mathrm{P}$.

With regard to $\mathrm{P}$ influx, results confirm what was previously reported by Sanders \& Tinker (1973), Smith (1982), Faquin et al. (1990), Smith (1990), Silveira (1990), Silveira \& Cardoso (1994) and Cunha (1999), that mycorrhizal plants present higher $\mathrm{P}$ influx in relation to 
non-mycorrhizal ones, under the same environment conditions. This means that for the same external concentration of $\mathrm{P}$, a mycorrhizal plant absorbs more $\mathrm{P}$ than a non-mycorrhizal one, probably because it has a higher $\mathrm{V}_{\max }$ or greater affinity to $\mathrm{P}$, i.e., a smaller $\mathrm{K}_{\mathrm{m}}$. Younger and mycorrhizal plants had greater net $\mathrm{P}$ influx per unit of root fresh weight because they had a smaller root yield associated with a greater $\mathrm{V}_{\max }$ (Table 1 and Figure $2 \mathrm{~A}$ ), which is confirmed by the negative and significant correlation between both $(r=-0.76)$. When the net influx was expressed per plant, the mycorrhizal plants surpassed the controls in both phenological stages (Figure 2B).

A smaller apparent $\mathrm{P}$ efflux (observed when the concentration of $\mathrm{P}$ in the solution becomes equal to zero, and can be calculated by the Michaelis-Menten equation; Figure 2) was verified for the mycorrhizal plants at 50 DAS, which was seven- and four-fold lower than in nonmycorrhizal plants, considering $\mathrm{C}-\mathrm{P}_{1}$ and $\mathrm{C}-\mathrm{P}_{2}$, respectively. This probably occurred because they presented greater root colonization and smaller $\mathrm{C}_{\min }$, therefore retaining more $\mathrm{P}$ in the root and/or hypha, which was translocated to the shoot. In addition, there was a positive and significant correlation $(P<0.007)$ between $\mathrm{K}_{\mathrm{m}}$ and $\mathrm{C}_{\text {min }}$ $(\mathrm{r}=0.61)$, suggesting that affinity to $\mathrm{P}$ and the ability to absorb it, when in low concentration in the solution, had the same tendency.

Smith (1982) verified that the percentage of colonization in clover roots affected $\mathrm{P}$ influx, which occurs especially in young plants (Smith, 1990; O'Keefe \& Sylvia, 1992), where the fraction of root colonization that is active is greater and shows abundant arbuscule development. In the present experiment, little colonization occurred in the younger plants (35 DAS) which, however, does not dismiss the possibility that it was more active, causing higher $\mathrm{V}_{\max }$ and $\mathrm{P}$ influx values. For the older plants, the higher $\mathrm{V}_{\text {max }}$ and influx values probably were a consequence of greater root colonization, which also reflected on a reduction of $\mathrm{C}_{\min }$.

The differences in behavior for mycorrhizal plants, in the present experiment, could be related to the colonized root length percentage, which was $190 \%$ higher at 50 DAS. Earliness in establishing symbiosis is essential to ensure adequate plant development in plants that grow under low $\mathrm{P}$ availability conditions, and especially for short-cycle crops.

Comparisons between mycorrhizal and non-mycorrhizal plants should only be made when their shoot dry matter yield, root:shoot ratio, and $\mathrm{P}$ content are similar, and when they are at the same developmental stage (Pacovsky et al., 1986). Based on this assumption, a nonmycorrhizal plant was utilized as a control, receiving a $\mathrm{P}$ dose $\left(30.0 \mathrm{mg} \mathrm{L}^{-1}\right)$ that ensured its adequate development; this was considered a well supplied plant, especially with regard to $\mathrm{P}$. At least during the pod-filling stage, for shoot dry matter and P content, mycorrhizal plants did not differ from the control that received the higher $\mathrm{P}$ dose $\left(\mathrm{C}-\mathrm{P}_{2}\right)$, which was, therefore, an adequate control (Table 2). When the kinetic parameters of phosphorus absorption were compared with the content and accumulated amount of $\mathrm{P}$ in the shoot, a negative and significant correlation was obtained $(P<0.01)$ between $\mathrm{C}_{\min }$ and $\mathrm{P}$ content $(r=-0.90)$ and $P$ accumulation $(r=-0.45)$. This suggests that this parameter was the most correlated with $\mathrm{P}$ absorption by the bean plant, especially under low P concentrations in the solution.

\section{CONCLUSION}

Bean plant mycorrhization promoted greater growth and $\mathrm{P}$ absorption by the plant and favorably influenced $\mathrm{P}$ absorption kinetic parameters $\left(\mathrm{V}_{\max }, \mathrm{K}_{\mathrm{m}}\right.$ and $\mathrm{C}_{\min }$ ), promoting greater $\mathrm{P}$ influx by plants at the flowering and pod-filling stages.

\section{REFERENCES}

AMBLER, J.R.; YOUNG, J.L. Techniques for determining root lenght of vesicular-arbuscular mycorrhizae. Soil Science Society of America Journal, v.41, p.551-556, 1977.

AYLING, S.M.; SMITH, S.E.; SMITH, F.A. Colonisation by arbuscular mycorrhizal fungi changes the relationship between phosphorus uptake and membrane potential in leek (Allium porrum) seedlings. Australian Journal of Plant Physiology, v.28, p.391-399, 2001.

CLAASSEN, N.; BARBER, S.A. A method for characterizing the relation between nutrient concentration and flux into roots of intact plants. Plant Physiology, v.54, p.564-568, 1974.

CRESS, W.A.; THRONEBERRY, G.O.; LINDSEY; D.L. Kinetics of phosphorus absorption by mycorrhizal and nonmycorrhizal tomato roots. Plant Physiology, v.64, p.484-487, 1979.

CUNHA, M.I.B. Parasitismo de fungos micorrízicos arbusculares e cinética de absorção de fósforo em plantas cítricas. Piracicaba: USP/ESALQ, 1999. 106p. (Dissertação - Mestrado).

DREW, M.C.; SAKER, L.R.; BARBER, S.A.; JENKINS, W. Changes in the kinetics of phosphate and potassium absorption in nutrient-deficient barley roots measured by a solution-depletion techique. Planta, v.160, p.490-499, 1984.

EDWARDS, J.H.; BARBER, S.A. Phosphorus uptake rate of soybean roots as influenced by plant age, root trimming, and solution $\mathrm{P}$ concentration. Agronomy Journal, v.68, p.973-975, 1976.

FAQUIN, V.; MALAVOLTA, E.; MURAOKA, T. Cinética da absorção de fosfato em soja sob influência de micorriza vesículo-arbuscular. Revista Brasileira de Ciência do Solo, v.14, p.41-48, 1990.

JUNGK, A.; BARBER, S.A. Plant age and the phosphorus uptake characteristics of trimmed and untrimmed corn root system. Plant and Soil, v.42, p.227-239, 1975.

KARUNARATNE, R.S.; BARBER, J.H.; BARKER, M. Phosphorus uptake by mycorrhizal and nonmycorrizal roots of soybean. Journal of Plant Nutrition, v.9, p.1303-1313, 1986.

KUCEY, R.M.N.; PAUL, E.A. Biomass of mycorrhizal fungi associated with bean roots. Soil Biology and Biochemistry, v.14, p.413-414, 1982.

NASCIMENTO FILHO, V.F.; LOBÃO, A.O. Detecção de ${ }^{32} \mathbf{P}$ em amostras de origem animal e vegetal por efeito Cerenkov, cintilação líquida e detector GM. Piracicaba: CENA/USP, 1977. 25p. (Boletim Científico, 48).

O'KEEFE, D.M.; SYLVIA, D.M. Chronology and mechanisms of P uptake by mycorrhizal sweet potato plants. New Phytologist, v.122, p.651-659, 1992.

PACOVSKY, R.S.; BETHLENFALVAY, G.J.; PAUL, E.A. Comparisons between P-fertilized and mycorrhizal plants. Crop Science, v.26, p.151$156,1986$. 
PHILLIPS, J.M.; HAYMAN, D.S. Improved procedure for clearing roots and staining parasitic and vesicular-arbuscular mycorrhizal fungi for rapid assessment of infection. Transactions of the British Mycological Society, v.55, p.158-161, 1970.

RUIZ, H.A. Estimativa dos parâmetros cinéticos Km e Vmax por uma aproximação gráfico - matemática. Revista Ceres, v.32, p.79-84, 1985

SANDERS, F.E.; TINKER, P.B. Phosphate flow into mycorrhizal roots. Pesticide Science, v.4, p.385-395, 1973.

SARRUGE, J.R.; HAAG, H.P. Análises químicas em plantas. Piracicaba, ESALQ/USP, 1974.

SILVEIRA, A.P.D. Micorrizas. In: CARDOSO, E.J.B.N.; TSAI, S.M.; NEVES, M.C.P. (Ed.) Microbiologia do solo. Campinas: SBCS, 1992. cap.19, p.257-282

SILVEIRA, A.P.D. Cinética da absorção de fósforo e estado nutricional do feijoeiro sob influência de micorriza vesículo - arbuscular. Piracicaba: USP/ESALQ, 1990. 130p. (Tese - Doutorado).

SILVEIRA, A.P.D.; CARDOSO, E.J.B.N. Efeito do fósforo e da micorriza vesículo-arbuscular na simbiose Rhizobium - feijoeiro. Revista Brasileira de Ciência do Solo, v.11, p.31-36, 1987.

SILVEIRA, A.P.D.; CARDOSO, E.J.B.N. Efeito da micorriza vesículoarbuscular e rizóbio nos parâmetros cinéticos de absorção radicular de ${ }^{32} \mathrm{P}$ pela soja. In: CONGRESSO BRASILEIRO DE MICROBIOLOGIA, 16., Santos, 1991. Resumos. Santos, 1991. p.55.

SILVEIRA, A.P.D.; CARDOSO, E.J.B.N. Phosphorus absorption by aluminum tolerant and intolerant soybean colonized by VA mycorrhizal fungus. In: EUROPEAN SYMPOSIUM ON MYCORRHIZAS, 4., Granada, 1994. Abstracts. Granada, 1994. p.258.
SMITH, S.E. Inflow of phosphate into mycorrhizal and non-mycorrhizal plants of Trifolium subterraneum at different levels of soil phosphate. New Phytologist, v.90, p.293-303, 1982.

SMITH, S.E. Phosphorus fluxes in vesicular-arbuscular mycorrhizal plants: relationships with infection and enviromental variables. In: NORTH AMERICAN CONFERENCE ON MYCORRHIZAE, 8., Jackson, 1990. Abstracts. Jackson, 1990. p.266.

SMITH, S.E.; GIANINAZZI-PEARSON, V.; KOIDE, R.; CAIRNEY, J.W.G. Nutrient transport in mycorrhizas: struture, physiology and consequences for the symbiosis. Plant and Soil, v.159, p.103-113, 1994.

VILARIÑO, A.; ARINES, J.; SCHÜEPP, H. Extraction of vesiculararbuscular mycorrhizal mycelium from sand samples. Soil Biology and Biochemistry, v.25, p.99-103, 1993.

VINCENT, J.M. A manual for the practical study of root-nodule bacteria. Oxford: Blackwell Scientific, 1970. 164p. (IBP Handbook, 15).

WARNCKE, D.D.; BARBER, S.A. Root development and nutrient uptake by corn grown in solution culture. Agronomy Journal, v.66, p.514$516,1974$.

Received June 04, 2002

Accepted December 12, 2003 